\title{
SPADA: Online learning between universities of PGRI Indonesia
}

\author{
Muhammad Nur Hudha ${ }^{1 *}$, Uwes Anis Chaeruman ${ }^{2}$, Sudi Dul Aji ${ }^{1}$, Choirul Huda ${ }^{1}$, Andista Candra Yusro ${ }^{3}$, Farida Nur \\ Kumala ${ }^{1}$, Wartono Wartono ${ }^{4}$, Asep Bayu Dani Nandiyanto ${ }^{5}$ and Ade Gafar Abdullah ${ }^{6}$ \\ ${ }^{1}$ Physics Education Study Program, Universitas Kanjuruhan Malang, J1. S. Supriadi no 48, Malang 65148, Indonesia \\ ${ }^{2}$ Departement of Educational Technology, Jakarta State University, Jl. Rawamangun Muka, Jakarta Timur 13220, Indonesia \\ ${ }^{3}$ Physics Education Study Program, Universitas PGRI Madiun, J1. Setiabudi No.85, Madiun 63118, Indonesia \\ ${ }^{4}$ Physics Departement, State University of Malang, Jl. Semarang 5, Malang 65145, Indonesia \\ ${ }^{5}$ Departemen Kimia, Universitas Pendidikan Indonesia, Jl. Dr. Setiabudi no 229, Bandung 40154, Indonesia \\ ${ }^{6}$ Departemen Pendidikan Teknik Elektro, Universitas Pendidikan Indonesia, Jl. Dr. Setiabudi no 229, Bandung 40154, Indonesia
}

\begin{abstract}
The blended learning model is a learning that uses online facilities combined with face-to-face learning (synchronous learning-asynchronous learning). The purpose of this research is to develop online learning that can be used by two PGRI universities in Indonesia as an online learning media. This research applies research and development method 4D Thiagarajan (Define, Design, Develop, and Disseminate). Data analysis technique used is descriptive qualitative data analysis. The result of this study is an online learning system that can be used by Universitas Kanjuruhan Malang and Universitas PGRI Madiun in Basic Physics course. This system uses the MOODLE (Modular Object-Oriented Dynamic Learning Environment), therefore it has the advantage that it is easy to use by all lecturers.
\end{abstract}

\section{Introduction}

Today's online learning helps the teacher in developing the quality of learning. The Online Learning System (SPADA) is one of the applications of educational technology, especially blended learning as a vehicle for credit transfer to solve one of the challenges of higher education in Indonesia, which is to improve access to higher quality education [1].

Blended learning model is a learning that uses online facilities combined with face to face learning (face to face) [2]. The blended learning paradigm has been widely practiced in universities [3]. Blended Lerning has been proven to increase student interest in learning [4], the quality of learning [5] [6], and can be utilized with e learning [7]. Blended learning can also be used as a learning evaluation tool [8]. However, the utilization of blended learning for learning which has been conducted by two universities in Indonesia is still not maximized.

This study aims to develop a learning tool that can be done by two universities through SPADA. Students from a certain college may attend an online course offered by another college. The value obtained through blended learning with other universities (credit learning) can be transferred (credit transfer) with the same value in the college where the student is enrolled [1].

\section{Methods}

The application development procedure is adapted from the 4D model (Define, Design, Develop, and Disseminate) [9]. The steps are arranged as in Figure 1.

\footnotetext{
* Corresponding author: muhammadnurhudha@unikama.ac.id
} 


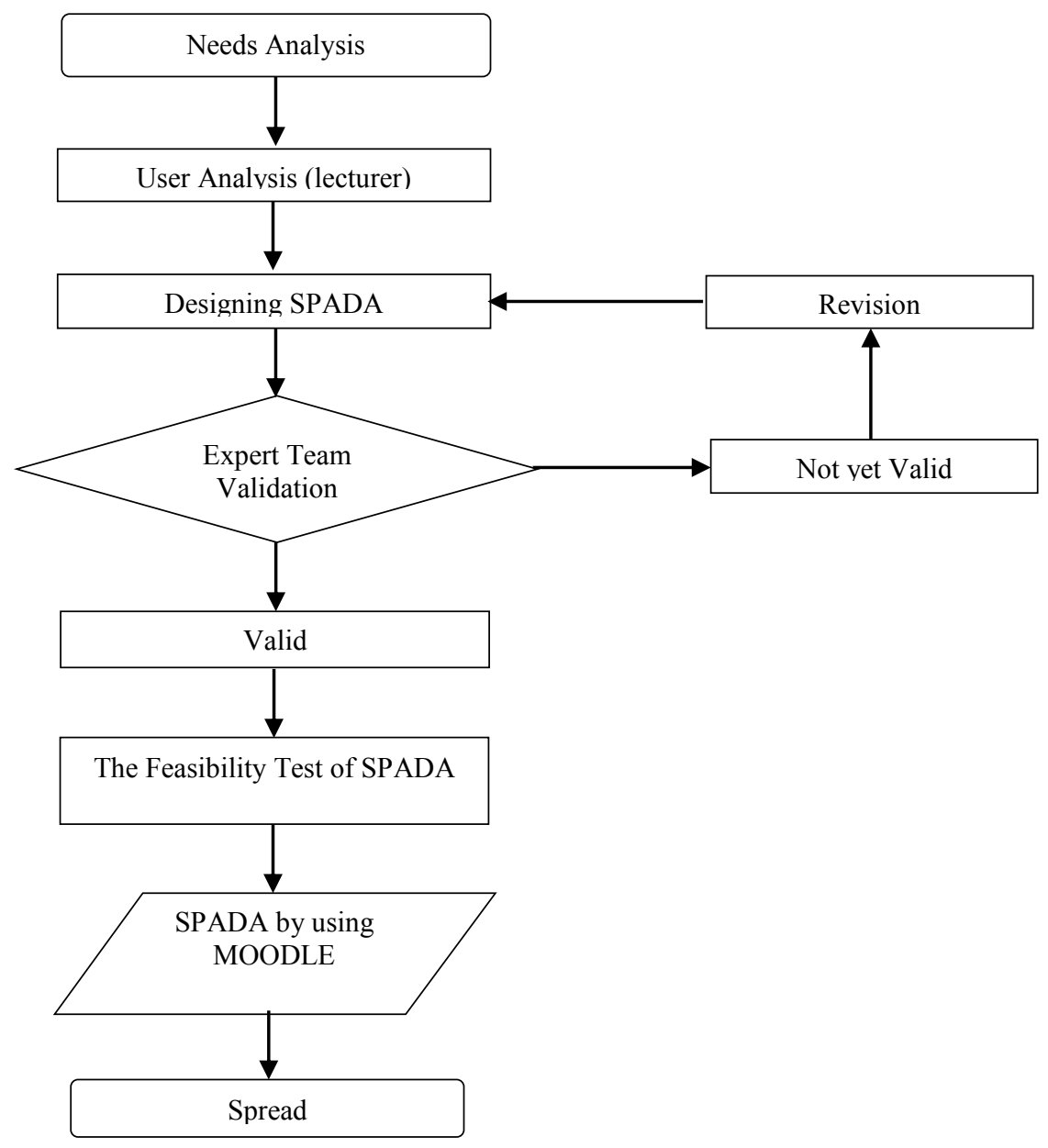

Fig. 1. Research Procedure.

In the early stages of the development, the Credit Transfer- Online Course is more directed to the arrangement of the guidelines for Credit TransferOnline Course, content development or e-course material at the administrator university, course content evaluation, standardization/alignment of Learning Management System (LMS) and Academic Information System (SIAKAD) at the administrator university.

The process of conducting the lecture is done by two PGRI universities, namely Universitas Kanjuruhan Malang (Unikama) and Universitas PGRI Madiun
(Unipma) that have signed an MoU. The reason of choosing Unipma as the partner of online learning of credit transfer is because Unikama and Unipma both have Physics Education Study Program. Basic Physics courses submitted for online lectures have the same credit of 3 credits and located in the same semester.

Learning Management System (LMS) that is utilized uses MOODLE applications. The LMS application can be viewed on http://spada.unikama.ac.id/. The creating process is presented in Figure 2. 


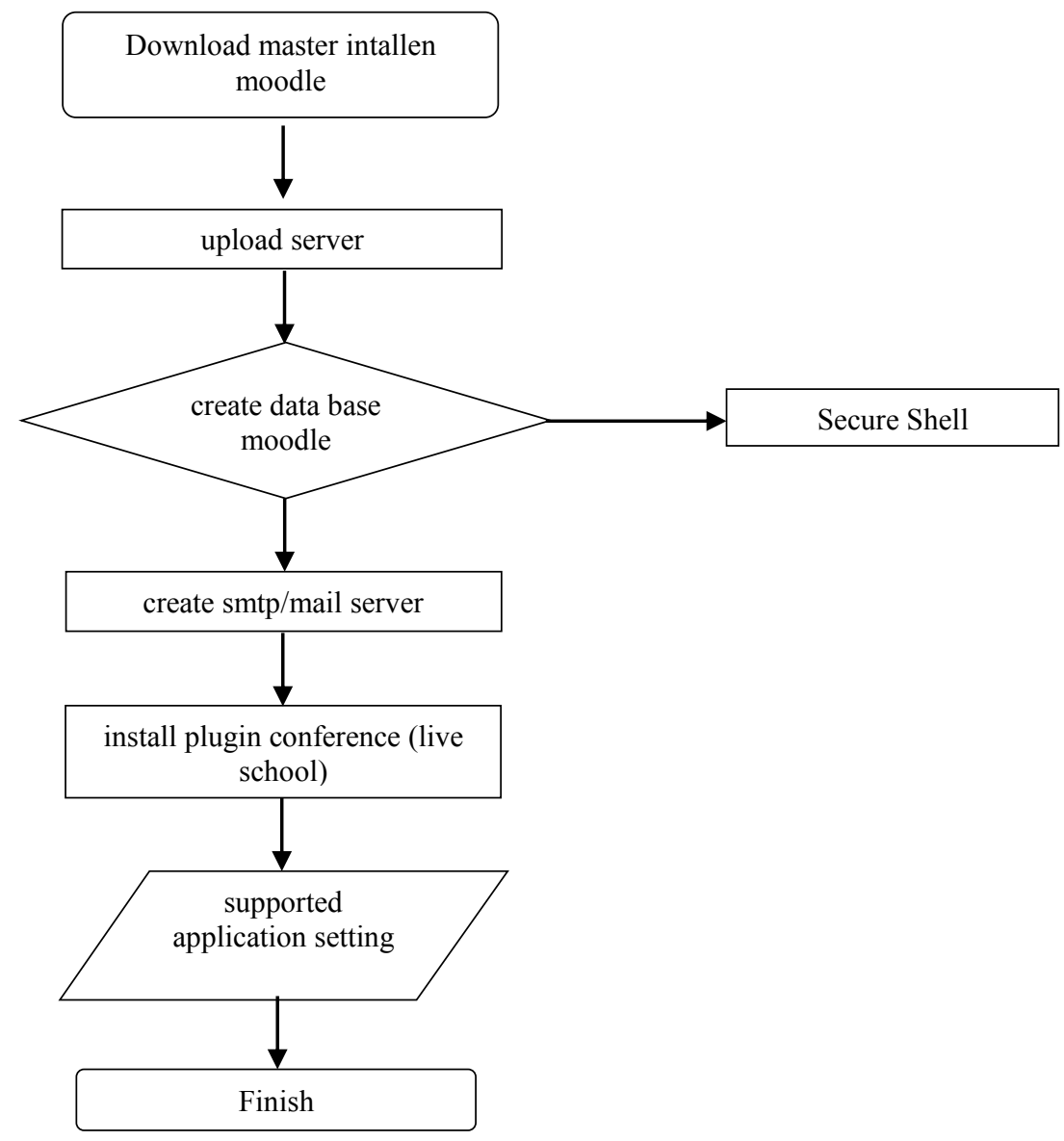

Fig. 2. Development Procedure of Learning Management System (LMS) of Unikama.

Implementation phase of Credit Transfer- Online Course in Basic Physics course with Unikama-Unipama begins on September $18^{\text {th }} 2017$ until January $5^{\text {th }} 2018$. Based on Unikma-Unipma Physics Education curriculum in Odd Semester of Academic Year 2017/2018, Basic Physics Course has the total number of students about 34 students. It consists of 22 Unikama students and 12 Unipma students.

\section{Results and Discussion}

The implementation of Basic Physics online lecture is conducted by Unikama and Unipma students. The steps of Basic Physics lecturing activities can be seen in Figure 3.

In this Credit Transfer- Online lecturing program, the registration of online participants will be collectively done through Unipma with Unikama. The entire process of Credit Transfer- Online lecturing will be recorded in the academic administration and academic system, starting from the registration of lecturers' subjects, course enrollment, offered subjects, registration of online participants, evaluation of learning outcomes and evaluation of learning process outcomes. 


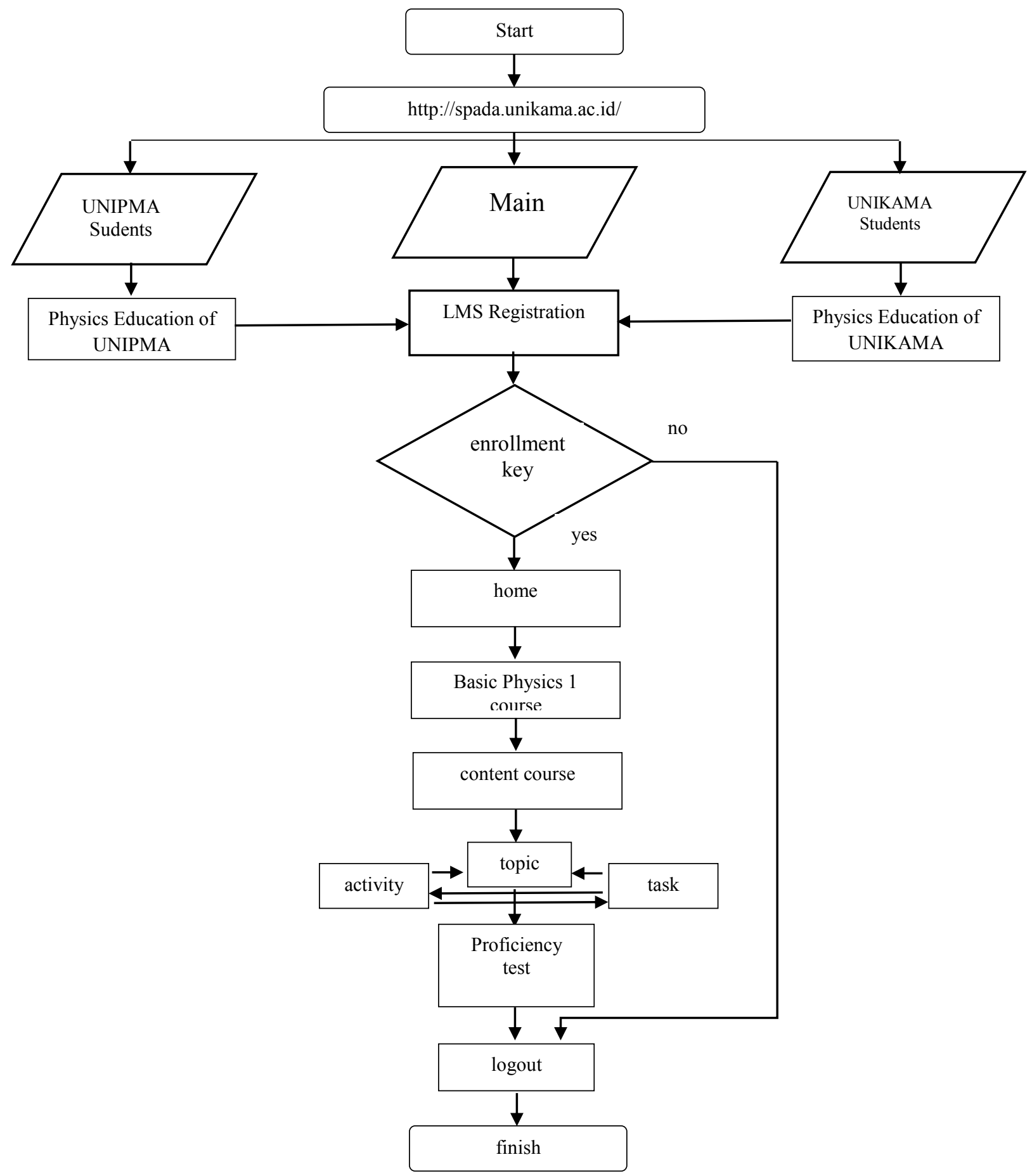

Fig. 3. Lecturing Process.

During the lecturing process, lecturers and tutors will always guide and monitor so that participants achieve competence in accordance with the achievement of learning. The role of tutors in blended learning is urgently needed [10]. Tutors and supervisors strongly support and enhance the learning process [11]. The lectures were organized during 16 meetings. They are 12 online lecture meetings and 4 face-to-face meetings.
At the end of the lecture, the participants will get a certificate as a sign of the online lecture participation from Unikama and the certificate consists of the numerical value given by the lecturer of the online course administrator. For the purposes of credit equalization, Unipma students must submit the certificate to the Physics Education study program of Unipma. LMS page views can be seen in Figure 4. 


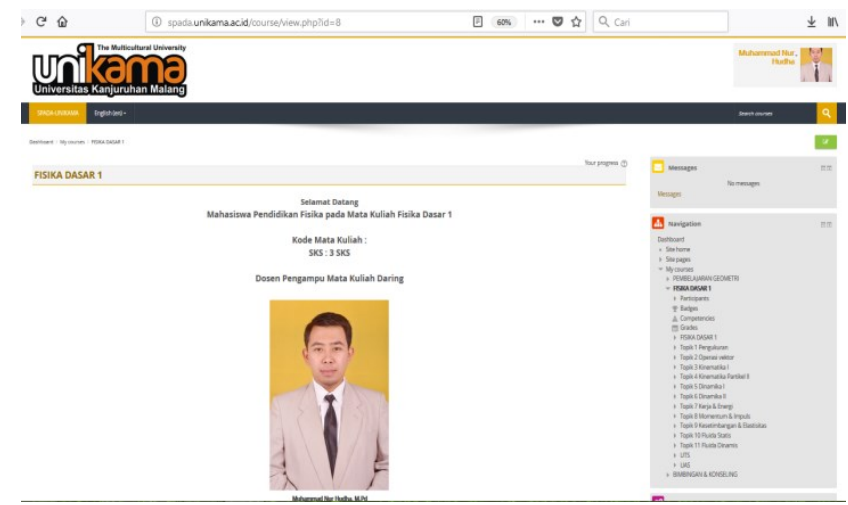

Fig. 4. Display of LMS Unikama.

The learning process uses a synchronous learning asynchronous learning model [1] [12]. Synchronous learning consists of direct or face-to-face synchronous and virtual synchronous. Implementation of the learning system can be seen on the page

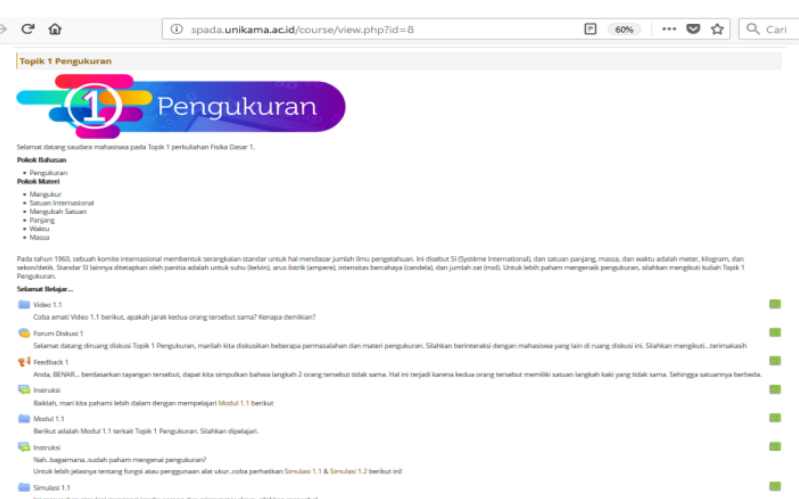

http://spada.unikama.ac.id while the implementation of virtual synchronous can be seen on page http://secure.live-school.net. An example of UnicamaUnipma's virtual synchronous can be seen in Figure 5.

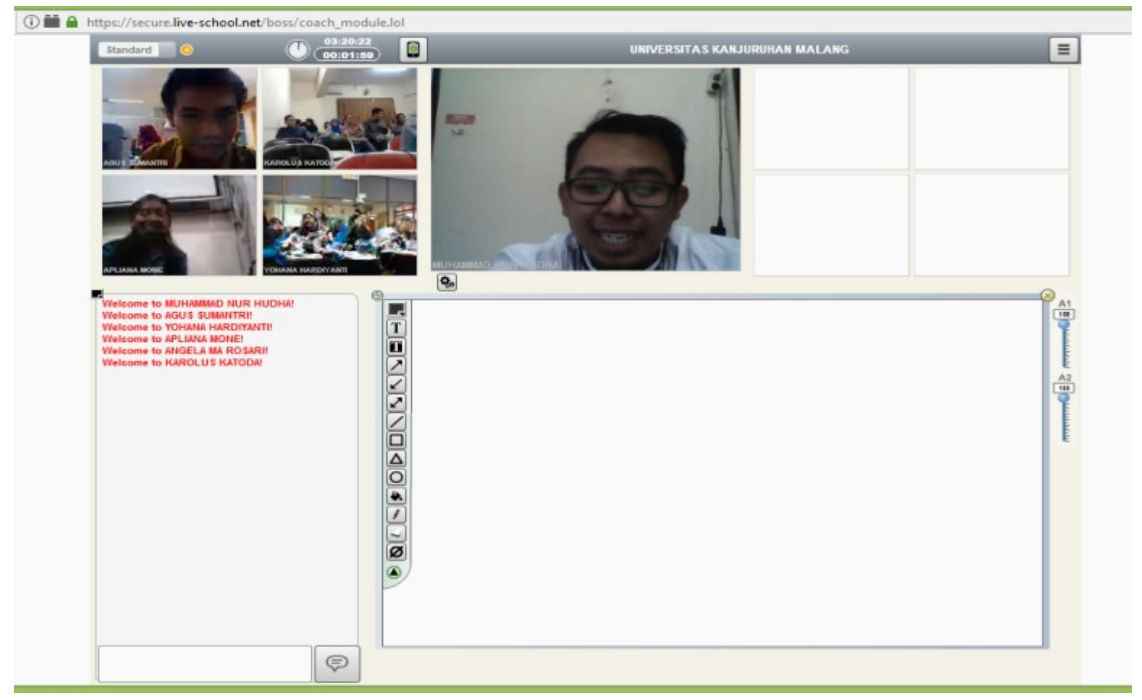

Fig. 5. Recording Sample of Virtual Synchronous Unikama-Unipma.

Virtual synchronous learning using video conference is considered excellent for creating a fun learning virtual environment [13]. Synchronous learning using multimedia technology such as video conference, web conference, and virtual world has been widely used [14]. Implementation of the use of this learning affects the academic performance and learning outcome [15].

\section{Conclusion}

The implementation process involving 2 universities under PGRI was just performed for the first time, so there were some constraints during the implementation process. These constraints include the students who were still confused with this particular lecture model, LMS Unikama previously unsynchronized with LMS DIKTI, so Unikama develop a new LMS which is appropriate with DIKTI, and weak internet network when synchronous virtual was done in the implementation of online learning. In addition to some of these weaknesses, there are also some advantages in the implementation of
SPADA learning, such as lecturers and students can learn anytime and sharpen the ability of students independently.

\section{References}

1. U. A. Chaeruman, B. Wibawa, and Z. Syahrial, "Determining the Appropriate Blend of Blended Learning: A Formative Research in the Context of Spada-Indonesia," vol. 6, no. 3, pp. 188-195, (2018)

2. R. Boelens, M. Voet, and B. De Wever, "The design of blended learning in response to student diversity in higher education: Instructors' views and use of differentiated instruction in blended learning," Comput. Educ., vol. 120, no. May 2018, pp. 197-212, (2018)

3. R. Kumar and N. Pande, "ScienceDirect Technology-mediated learning paradigm and the blended learning ecosystem: what works for working professionals?," Procedia Comput. Sci., 
vol. 122, pp. 1114-1123, (2017)

4. P. Kharb and P. P. Samanta, "Journal of the Anatomical Society of India Blended learning approach for teaching and learning anatomy: Students ' and teachers ' perspective," Indian J. Rheumatol., vol. 65, no. 1, pp. 43-47, (2016)

5. E. Coyne, V. Frommolt, H. Rands, V. Kain, and M. Mitchell, "NU SC," Nurse Educ. Today, vol. 66, no. July 2018, pp. 96-102, (2018)

6. H. M. Vo, C. Zhu, and N. A. Diep, "Studies in Educational Evaluation The effect of blended learning on student performance at course-level in higher education: A meta-analysis," Stud. Educ. Eval., vol. 53, pp. 17-28, (2017)

7. H. El-deghaidy and A. Nouby, "Effectiveness of a blended e-learning cooperative approach in an Egyptian teacher education programme," Comput. Educ., vol. 51, no. 2008, pp. 988-1006, (2008)

8. S. Hubackova and I. Semradova, "Evaluation of Blended Learning," Procedia - Soc. Behav. Sci., vol. 217, no. 2016, pp. 551-557, (2016)

9. S. D. Aji, M. N. Hudha, C. Huda, A. B. D. Nandiyanto, and A. G. Abdullah, "The Improvement Of Learning Effectiveness In The Lesson Study By Using E-Rubric," J. Eng. Sci. Technol., vol. 13, no. 5, pp. 1181-1189, (2018)

10. B. F. Klimova and P. Poulova, "Tutor as an important e-learning support," Procedia Comput. Sci., vol. 3, pp. 1485-1489, (2011)

11. T. Krasnova and M. Demeshko, "Tutor-mediated Support in Blended Learning," Procedia - Soc. Behav. Sci., vol. 166, pp. 404-408, (2015)

12. U. A. Chaeruman and S. Maudiarti, "Jurnal Pembelajaran Inovatif Quadrant of Blended Learning: a Proposed Conceptual Model for Designing Effective Blended Learning," vol. 1, no. 4, pp. 1-5, (2018)

13. C. A. Warden, J. O. Stanworth, J. Biao, and A. R. Warden, "Computers \& Education Synchronous learning best practices : An action research study," Comput. Educ., vol. 63, pp. 197-207, (2013)

14. M. Bower, B. Dalgarno, G. E. Kennedy, and M. J. W. Lee, "Design and Implementation Factors in Blended Synchronous Learning Environments: Outcomes from a Cross-Case Analysis," Comput. Educ., vol. 86, pp. 1-17, (2015)

15. M. Mehri and M. Uplane, "Synchronous and asynchronous e-learning styles and academic performance of e-learners," Procedia - Soc. Behav. Sci., vol. 176, pp. 129-138, (2015) 